\title{
Çokkültürlülük Olgusunun Kanada Örneği Ekseninde İncelenmesi
}

\author{
*Emrah Bașaran \\ * Arş. Gör., Necmettin Erbakan Üniversitesi, Sosyal ve Beşeri Bilimler Fakültesi, Sosyoloji Bölümü, \\ Meram/ Konya/ Türkiye \\ E-Posta: ebasaran@konya.edu.tr \\ ORCID: 0000-0003-0389-9069
}

Öz

İçerisinde yaşadı̆̆ımız dünya son yüzyılda ortaya çıkan ve takip edilebilmesi neredeyse imkansız olan birçok gelişme sonrasında artık küresel bir köy haline gelmiştir. Son dönemde özellikle dikkati çeken teknoloji ve ulaşım alanında görülen ilerlemelerle birlikte toplumsal yapılarda hızla değişmekte ve ortaya çıkan yeni tartışma ve problemler gündemi meşgul etmektedir. Bu sorunlar sıralamasında ise çokkültürlülük ekseninde değerlendirilen "birlikte yaşama" problemi sosyolojik, siyasal ve hukuksal anlamda yoğun tartışmaların yapılmakta olduğu konuların başında gelmektedir. Küreselleşmeyle birlikte daha da görünür hale gelen uyum ve entegrasyon sorunlarn tüm dünya ülkelerinde olduğu gibi Kanada'nın da gündemini sürekli meşgul etmektedir. Bir göçmen ve mülteci ülkesi olan Kanada üretmiş olduğu politikalar nedeniyle çokkültürlülük tartışmalarında merkezi bir konumda bulunmaktadır. Kanada'nın çokkültürlü bir toplum görünümünde olması ise çokkültürlülük tartışmalarının yapılmadığı anlamına gelmemektedir. Kanada'nın uzun yıllardan beri tartıştığı konulardan en önemlisini Quebec bölgesinde yaşayan Fransızların vermiş oldŭ̆u bă̆ımsızlık mücadelesi oluşturmaktadır.

Anahtar Kelimeler: Çokkültürlülük, Entegrasyon, Asimilasyon, Kanada 
ISSN:2528-9527

E-ISSN : 2528-9535

YIl Year: 7

Cilt Volume:7

Sayı Issue : 12

Uluslararası Toplum Araştırmaları Dergisi

International Journal of Society Researches

Haziran June 2017

Makalenin Geliş Tarihi Received Date: 24/05/2017

Makalenin Kabul Tarihi Accepted Date: 20/06/2017

\title{
An Investigation on The Notion of Multiculturalism Within The Scope of Canada Case
}

\begin{abstract}
The world we live in has now become a global village after many developments that occurred in the last century and are almost impossible to follow. Recent developments in the area of technology and transportation, which are particularly striking, are rapidly changing in social structures, and new debates and problems are on the agenda. In the order of these problems, the issue of "coexistence", which is evaluated on the axis of multiculturalism, comes at the forefront of intense debates in sociological, political and legal sense. Along with globalization, Canada's agenda is constantly occupied, as it is in all the countries of the world, as harmonization and integration problems become more visible. Canada, a country of immigrants and refugees, is in a central position in multicultural debates due to policies it has produced. The fact that Canada looks like a multicultural society does not mean that multicultural debates have not been done. The most important issue that Canada has been discussing for many years is the struggle for independence, given by the French living in the Quebec region.
\end{abstract}

Key Words:. Multiculturalism, Integration, Assimilation, Canada 


\section{Giriş}

Çokkültürlülük kavramı açıklanmadan önce bu kavramın hangi şartlar sonucunda ortaya çıktığının bilinmesi şüphesiz ki konuyu daha anlaşılır ve anlamlı bir hale getirecektir. İçinde yaşadığımız 21. yüzyıl her anlamda ve boyutta 20. yüzyılda meydana gelmiş olan değişim ve gelişimlerin 1ş1ğında yaşanan bir yüzyıldır. 20.yüzyıl içerisinde cereyan eden birinci ve ikinci dünya savaşları, ekonomik krizlerin patlak vermesi, ülkeler ve kıtalar arası yaşanan zorunlu/gönüllü göçler, iletişim, teknoloji ve ulaşım alanında meydana gelen olağanüstü değişimler gibi daha farklı birçok olayın cereyan etmesi dünyanın görüntüsünü tamamen farklılaştırmaya yetmiştir. Bu gelişmeler sonucunda oluşan yeni dünya düzeninde ise bir tarafta Avrupa diğer tarafta da ABD' nin önemli bir rol üstlendiği açıkça görülmektedir. Bu iki kutuplu merkez güdümünde ülkelerin sınırlarının tekrar çizilmeye başlandığı bu dönemde, farklı kültürlere mensup bireylerinde bu çeşitli faktörler nedeniyle bu kutup ülkelerin çevrelerinde toplanmaya başladıkları görülmektedir. Yine bu yeni dünya düzeni içerisinde iletişim aygıtlarının yaygınlaşmasının sonucunda bilgiye kolay ulaşabilme imkanının doğması, farklı kültürlerin birbirlerini tanımalarına ve birbirlerinden etkilenmelerine fırsat tanımıştır. Dolayısıyla bu kültür ve kimlik çeşitliliği aynı zamanda da bir uyum problemini de ortaya çıkarmıştır. Bu kadar farklı kimliklerin bir anda aynı ortamda yaşamaya başlaması Kanada gibi çok fazla göçmen nüfusa sahip ülkeleri düşündürmekte ve çokkültürlü yapıların nasıl uyum içerisinde yaşayabileceği konusunda politikalar üretmeye zorlamaktadır.

Dünya'da son birkaç yüzyılda ortaya çıkan tabloya bakıldığında tarihin hiçbir döneminde olmadığı kadar çok farklı kültürlerin bir arada yaşama fırsatına sahip oldukları görülmekte ancak diğer bir açıdan bakıldığında ise yine bu dönemde geçmişte görülmediği kadar ırkçı saldırıların arttığı bilinmektedir. Bu bağlamda ortaya çıkan iki kutuplu bir olgusal durum, yani çokkültürlülük ve ırkçılık tartışmaları dünyanın gidişatını belirlemede önemli bir yere sahiptir. Sadece son dönemde yaşanan birkaç olaya bakıldığında bile özellikle demokrasi, özgürlük, insan hakları konusunda dünyaya örnek olduklarını ifade eden Batı ülkeleri ve Amerika'da insanlar ten rengi farklı oldukları için veya kıyafetlerinden dolayı saldırı- 
lara maruz kalabilmektedirler. Yine özellikle Batı ülkelerinde dinsel gerekçelerle "Müslümanlar" bir takım ayrımcılıklara maruz kalmaktadırlar*.

Birçok farklı boyuttan oluşan bir kavram olan çokkültürlülük olgusu tartışılırken genellikle ulus, ırk, milliyetçilik, ayrımcılık vb. bağlamlarda değerlendirilmektedir. Bu çalışmada ise bu kavramlar bağlamında bir tartışmaya girilmeyerek çokkültürlülük kavramının genel anlamda neler ifade ettiği üzerinde durulacak, bu kavramın ortaya çıkışı ve bu kavramla ilgili politikalar üretilmesi açısından öncü ülkelerden olan Kanada'nın çokkültürlü bir devlet olma yolunda izlediği politikalar bağlamında konu tartışılmaya çalışılacaktır.

\section{Çokkültürlülük Kavramının Anlatmak İstedikleri}

Modern dönemde ilk olarak Avrupa'da ortaya çıkan ulus-devlet yapılanması günümüz küresel çağında birçok sorun ve yeniliklerle karşılaşmaktadır. Bu sorun ve yeniliklerin başında ise çokkültürlülük olgusu gelmektedir. Günümüzde birçok devletin kültürel çeşitlilik gerçeğiyle iç içe olması ulus devletlerin simgelerinden olan marşların ve bayrakların kimleri ve neyi temsil ettiği noktasında bir belirsizlik oluşturmaktadır (Şan, 2016, s.131-132). Bu bağlamda değerlendirildiğinde ise çokkültürlülük olgusunun ana eksenini, dünyanın farklı coğrafyalarında yaşayan ve ulus-devleti ifade eden kültürel değerlerden farklı olarak, gündelik yaşamlarında kendilerine özgü kültürel değerlerle yaşamak isteyen kesimlerin vermiş oldukları tanınma mücadelesinin oluşturduğu görülmektedir (Anık, 2012a, s.118).

İnsanlık tarihi kadar eski bir olgu olan çokkültürlülük, tarihte Osmanlı İmparatorluğu gibi birçok imparatorluk tarafından uygulanmış ve bu imparatorluklar farklı kültürlerin bir arada yaşayabilmesinin yollarını bulmuşlardır. İkinci dünya savaşı öncesi duruma bakıldığında, bu dönemde Batı'da kültürel ve dinsel çeşitlilik çok az görülebilen ve desteklenen bir

\footnotetext{
* Özellikle 11 Eylül saldırılarından sonra Amerika'da ve Batı'da Müslüman bireylere karşı başlayan ırkçı saldırılar sonucunda oluşan durumun kavramsallaş̧ııılmış hali islamofobi'dir. Yayınlanan birçok raporda ve yapılan çalışmalarda Avrupa ülkelerinde yabancılara ve özellikle Müslamanlara karşı yapılan ırkçı saldırılarda ciddi bir biçimde artış yaşandığı herkesçe bilinmektedir. Ancak bu tartışma başka bir çalışmanın konusu olduğu için burada tartışılmayacaktır.
} 
şeydi. Batı'daki antidemokratik yapılanmaya sahip olan hiyerarşi, bazı ırkların diğerlerinden üstün olduğu düşüncesiyle hareket etmekte ve bu düşünce biçimi Batı dünyasında kabul görmekteydi. İkinci dünya savaşından sonra ise Hitler'in yapmış olduğu katliamların ardından BM'nin de desteklemesiyle irkların ve halkların eşit olduğu düşüncesi etkili olmaya başladı. Bu gelişmeler sonrasında ise 3 boyutta değerlendirilebilecek bir dizi politik hareket ortaya çıktı. İlk olarak 1948-1965 yılları arasında kolonileşme hareketlerine karşı bir tavır takınıldı. İkinci olarak ise ırksal ayrımclığa karşı bir mücadele ortaya konulmaya başlandı. Son olarak da 1960'larda çokkültürlülük için verilen mücadeleler ortaya çıkmaya başladı (Kymlicka, 2012, ss. 5-6). Batı demokrasi tarihi incelendiğinde 1970'lerden 1990'lı yılların ortalarına kadar, çokkültürlülük politikalarının uygulanması ve azınlık haklarının tanınması yönünde Batı ülkelerinde ciddi bir görüş birliğinin olduğu görülmektedir. Bu politikalar gerek devlet nezdinde gerekse uluslararası kuruluşlar seviyesinde desteklenmekte ve homojen bir toplum olmakla ilgili eski fikirler reddedilmekteydi. Ancak 1990'lı yıllardan sonra bu çokkültürlülük politikalarından vazgeçildiği görülmektedir. Bu vazgeçişin nedeni, kısmi olarak çoğunluk grubu içerisindeki çeşitlilikten kaynaklanan uyumun çok ileri giderek onların yaşam düzenini tehtid ettiği korkusundan kaynaklanmaktadır. Bu korkuların pratikteki yansıması ise yerlileri bir arada tutan sağcı politikaların yükselmesi şeklinde gerçekleşmiştir (Kymlicka, 2012, s.3).

Özellikle son dönem Avrupa siyaseti incelendiğinde radikal sağ tandanslı partilerin yükselişe geçtikleri açıkça görülebilmektedir. Bu partilerin İslam karşıtlı̆̆ ve göçmen karşıtlığı konularında ortak özelliklere sahip olması ise çokkültürlü bir toplum olma yolunda Batı'nın çok istekli olmadığını göstermektedir.

Günümüz dünyasında çokkültürlülügün tartışılması Kuzey Amerika'daki azınlıkların hakları ve İkinci dünya savaşı sonrasında Amerika kıtasına ve Batı Avrupa'ya doğru yoğun göçlerin yaşanması sonucunda başlamıştır. Bunlara ek olarak küreselleşmenin sunduğu imkanlar ile ulus devletlerin politikalarının kültürel çeşitliliğe imkan tanımaması bu kavramı tartışmaların odak noktası haline getirmiştir. Çokkültürlülük kavramının hedefinde, aynı toplum içerisinde yaşayan farklı kültürel kimliklere sahip kişilerin birbirleriyle olan ilişkilerinde çatışma yaşamadan barış içerisinde yaşaması ve politik haklardan eşit bir biçimde yararlanması vardır 
(Özensel, 2013a, ss.5-6). Modern anlamda ise çokkültürlülüğün kökenlerini Kuzey Amerika'da görmemiz mümkündür. Çokkültürlülük, $A B D$ ve Kanada'da yaşayan ve farklı dilleri konuşan insanların kendi topraklarında kültürel kimliklerinin tanınmasını talep etmesi sonucunda ortaya çıkmış bir olgudur (Özensel, 2013b, s.40).

Farklı kültürlerin uyum içerisinde nasıl bir arada yaşayabileceği konusunda fikirler üreten Charles Taylor çokkültürlülük konusunda evrensel hak anlayışına vurgu yapmaktadır. Ona göre herkesin kendi olma hakkı ve kapasitesi olmalıdır. Kimsenin bir başkasının değerini eleştirme hakkı da yoktur. Bir kişinin kendini gerçekleştirmesinin sınırı, bunu gerçekleştirmek için başkalarının da sahip olduğu eşit şansı garanti altına almasıyla gerçekleşebilir (Taylor, 1995, s.42). Çokkültürlülük bir bakıma çeşitlik vurgusu da yapmaktadır. Bu çeşitlilik cansız ve durağan olmayıp, aksine insanların yaşadıkları coğrafya, içinde bulundukları ortam ve daha birçok etmene bağlı olarak oluşan hareketli bir yapının ifadesidir. Dolayısıyla böyle bir çeşitlilik bizi parçalara ayırmak yerine, birleştirici bir rol üstlenmelidir (Strauss, 1995, ss. 21-24). Ancak tarihsel süreç içerisinde farklı birçok toplumda kültürel farklılıklar siyasi birlikteliğin gerçekleştirilmesi yolunda en büyük engeli teşkil etmiştir. Çünkü her kültürün sahip olduğu değerler bir başka kültürle kıyaslanamaz önceliğe sahip görülmektedir (Özensel, 2012, s. 57). Dolayısıyla farklı kültürlere ait bireyler sorunsuz bir şekilde aynı ortamda yaşamak istiyorlarsa öncelikle bu çeşitliliğin onlar için bir kazanım olduğunun farkına varmaları gerekmektedir. Bu farkındalık düzeyi ne kadar artarsa ve yüksek olursa sorunlarda bu farkındalık düzeyiyle ters orantılı olarak azalacaktır. Çünkü kendisi dışındaki kültürlerin farkına varan yani onları anlayan bir birey aynı zamanda da bu durumu kabullenmeye de başlamıştır.

Çokkültürlülük bir kavram olarak Dünya'da ilk defa 1957 yılında İsviçre'de kullanılmış olsa da 1960'ların sonunda Kanada'da kullanılmasıyla yaygınlık kazanmış ve bu kavram hızlı bir şekilde İngilizce konuşan diğer ülkelere de yayılarak kullanılmaya başlanmıştır (Sengstock, 2009, s.239). Çokkültürlülük olgusu, içerisinde birden fazla anlam taşıyan, bir tekilliği değil çoğullu ifade eden bir kavramdır. Çokkültürlüllüğün birden çok tanımlaması yapılabilmekle birlikte bu kavramı genel anlamda basitçe şöyle tanımlamak mümkündür: Çokkültürlülük, farklı ve çok çeşitli kül- 
türlerin uyum içerisinde bir arada yaşayabilmesidir. Bir başka deyişle çokkültürlülük, bir kültüre ait olan ya da hisseden bireyin, başka bir kültüre ait bireyin kültürel alanına müdahale etmemesini, o bireyin mensup olduğu kültürle ilgili yorumda bulunurken kendi kültürünün özelliklerini dikkate almamasını ve belki de en önemlisi ona saygı ve hoşgörü çerçevesinde yaklaşmasını gerektirmektedir.

Çokkültürlülük modern bir kavram olmasına karşın kültürlerin tarihi insanlık tarihi kadar eski bir geçmişe sahiptir. Bu nedenle yüzyıllardan bu yana birbirlerinden çok farklı özelliklere sahip kültürler bir arada yaşamışlardır. Bu bir arada yaşama durumunda ise bir takım uyumsuzlukların ve problemlerin ortaya çıkması 'nasıl uyum içerisinde birlikte yaşayabiliriz’ sorusunu yani bu sorunun kavrama dönüşmüş hali olan çokkültürlülük olgusunu ortaya çıkarmıştır.

Bir başka açıdan değerlendirildiğinde çokkültürlülük, salt farklılıklar ve kimliklerle ilgili bir kavramı ifade etmemekte, kültürle kaynaşmış, iç içe geçmiş ve ondan beslenen farklllık ve kimliklerle, yani bir grup insanın kendilerini ve dünyayı anlamakta, bireysel ve toplu yaşamlarını düzenlemekte kullandıkları inançlar ve uygulamalar bütünüyle de alakalıdır (Parekh, 2002, s.3).

Çok boyutlu ve anlaşılması zor bir kavram olarak değerlendirilebilecek olan çokkültürlülük, küreselleşen dünyada çeşitliliklerin artmasının bir sonucu olarak gündemdeki yerini korumaktadır. Özellikle politik anlamda belirleyici bir güce sahip olması çokkültürlülük olgusunu sosyolojik anlamda daha değerli bir hale getirmektedir. Dünya üzerindeki birçok ülkenin çokkültürlü bir toplum olma yönünde politikalar üretiyor olması da çokkültürlü bir düzenden geriye dönüşün pek mümkün olamayacağını ifade etmektedir.

\section{Kanada'nın Tarihsel Oluşum Süreci}

Birçok kaynakta Kanada'nın, Asya'dan gelen halkların Bering Boğazı'nı kullanarak Atlas Okyanusu kıyılarına gelip burayı bir yerleşim alanı olarak oluşturdukları kabul edilmektedir. Bu bilgi tartışmalı olsa da Kanada'nın coğrafi keşiflerle birlikte eski kıtadaki insanların göç etmesiyle oluştuğu düşüncesi genel kabul görmektedir. Kanada, tarih boyunca Fransızların ve İngilizlerin egemenliği altına girmiştir. Bölgede süren 
uzun çatışmalardan sonra ise 1867 yılında tesis edilen Kuzey İngiliz Amerika'sı Akdi ile günümüz Kanada'sının temelleri atılmıştır (Özensel, 2012, ss.62-63). Kanada meşruti monarşi ile yönetilen bir ülkedir. Queen 2. Elizabeth devletin başıdır ve Başbakan'ın tavsiyesiyle atanan bir genel vali tarafından temsil edilmektedir. Hükümet bir federal sistemdir. Eyaletler vergi, eğitim, sağlık, mülkiyet ve vatandaşlık hakları gibi birçok alanda söz sahibidir. Hükümet ayrıca yasama, yürütme ve yargı gücünü elinde bulundurur. Yürütme Başbakan ve kabineye aittir. Yasama ise Avam Kamarası ve Senato' dakilerin elindedir (Bağlı ve Özensel, 2005, ss.74-76).

Parlementer demokrasi ve anayasal monarşi ile yönetilen Kanada, kurucu millet olarak İngiliz ve Fransızların kabul edildiği ve bu nedenle de İngilizce ve Fransızcanın resmi dil olarak konuşulduğu bir ülkedir. 1541 yılında ilk kez Fransızlar tarafından Quebec ve çevresine yerleşim yerleri inşa edilmiştir. Bu bölgede geçmişte İngilizler ve Fransızlar arasında kürk ticaretinden kaynaklanan savaşlar yapılmış ve 1791 yılında kabul edilen Kanada anayasası ile Fransızların çoğunluğu oluşturduğu Aşağı Kanada ve İngilizlerin çoğunlukta olduğu Yukarı Kanada olarak ikiye ayrılmıştır. Kanada Rusya'nın ardından yüzölçümü bakımından dünyanın ikinci büyük ülkesidir. Ancak nüfus bakımından ise 2007 verilerine göre 32 milyon civarında bir nüfusa sahip olması dikkat çekicidir. Kanada tam bir göçmen ülkesi olup İtalya, İrlanda, Almanya, Danimarka, İngiltere, Fransa gibi birçok farklı ülkeden gelen insanlardan oluşmaktadır. Kanada 19912000 yılları arasında iki milyondan fazla göçmeni kabul etmiştir. Kanada' da her yılın 27 Haziran'ı ise "Kanada Çokkültürcülük Günü" olarak kutlanmaktadır (Anık, 2012b, ss.140-141).

Kanada, yaşam standartlarına ve nüfusunun okuma oranlarına bakılarak Birleşmiş Milletler tarafından sürekli olarak en iyi yaşam kalitesine sahip ülkeler arasında gösterilmektedir. Kanada ismi ise köy ve yerleşim kelimesi olan 'Kanata' dan gelmektedir. Ülkenin ulusal renkleri kırmızı ve beyazdan oluşmaktadır. Tarihsel süreç içerisinde bugünkü Kanada' nın kurulmasında önemli role sahip İngiltere ve Fransa' nın renkleri olan kırmızı ve beyaz Kanada' nın ulusal renkleri olarak tespit edilmiştir (URL-1). Ülke doğal kaynaklar ve sanayileşme bakımından da oldukça gelişmiş bir düzeydedir. Kanada, fosil yakıt kaynakları, nükleer enerji üretimi ve hidro-elektrik güç üretim imkânları ile enerji bakımından kendi kendine yetebilen bir ülkedir (URL-2). 


\section{Kanada'nın Çokkültürlülük Pratikleri}

Kanada dünyada çokkültürlülük politikaları bakımından en önde olan ve bu konunun üzerinde ciddiyetle duran ülkelerin başında gelmektedir. Kanada' nın gerek tarihsel gerekse toplumsal zemini bir bakıma ülkeyi bu tarzda pratikler üretme konusunda zorunlu kılmıştır. Kanada bir göçmen ülkesi olması hasebiyle toplumsal uyum ve istikrar meselelerinde önemli tecrübelere sahip bir ülkedir. Bu nedenledir ki ülke çokkültürlülük konusunda karar kılan bir konumdadır (Vatandaş, 2001, s.104). Çok fazla göçmen alan bir ülke olan Kanada bu kadar çeşitli ırktan ve kültürden gelen bireyleri nasıl uyum içerisinde bir arada tutabileceği konusunda sürekli düşünen ve pratikler üretmeye çalışan ve bu konuda dünyaya bir ideal model olma yolunda ilerleyen bir ülke görünümündedir.

Kanada' nın resmi olarak çokkültürlülük çalışmalarına başlaması Başbakan Trudeau'nun 1971 yılında Avam Kamarası'nda yapmış olduğu konuşmasıyla gerçekleşir. Bu konuşmasında Trudeau, çokkültürlülük politikasının amacının kültürel kıskançlıkların ve ayrılıkçı tutumların yıkılması olduğunu belirtir (Forbes, 2007, s.27). Kanada'nın çokkültrlülük geçmişinde Başbakan Pierre Trudeau'nun önemli bir rolü bulunmaktadır. Trudeau 1968-1984 yılları arasında dört dönem Başbakanlık görevini yürütmüş ve bu dönemde göç serbest hale getirilerek çokkültürlülük teşvik edilmiştir. Ayrıca Trudeau'nun Başbakanlık döneminde Charter of Rights and Freedoms (Hak ve Özgürlükler Temel Yasası)'nı çıkarmış olması çokkültürlülügün güvence altına alınmasında önemli bir adım olarak görülmektedir (Özensel, 2012, s.63). Bu yasa ile artık Kanada mahkemelerindeki davalarda çokkültürlülük olgusunun dikkate alınması gerekliliği vurgulanmış, diğer bir deyişle çokkültürlülük uygulamaları en üst seviyede bir resmiyete kavuşmuştur.

Kanada'nın çokkültürlülük politikaları tanımlanırken kullanılan en önemli metafor "salata kasesi" (salad bowl) olarak ifade edilmektedir. Bu durum Amerika' da ise "erime potası" (melting pot) olarak karşılığını bulmaktadır. Burada anlatılmak istenen ise, Amerikan tarzı bir çokkültürlülüğün bireyleri bir eritme potasında dönüştürerek farklı bir kültürel forma soktuğu ancak Kanada çokkültürlülüğünde tıpkı bir salatayı oluşturan sebzelerdeki çeşitlilik gibi her farklı kültürün serbestçe yaşayabileceğine 
vurgu yapılmaktadır. Bu anlamda da Kanada tarzı bir çokkültürlülük modeli ortaya çıkmakta ve bu özelliğiyle de Kanada, Amerika ve Avrupa merkezli çokkültürlülük yaklaşımlarından ayrılmaktadır.

1996 yılında Kanada hükümeti farklı etnik ve dinsel grupların taleplerini değerlendirip özgürlük alanlarını genişletme işlerini düzenlemek üzere özel bir çokkültürlülük bakanlığı kurulmasını kararlaştırmıştır (URL-3). Bu çokkültürlülük bakanlığı bu konuyla alakalı 3 temel esas belirlemiştir. Bunlardan birincisi sosyal adalet, ikincisi yurttaşlıkla ilgili katılımı sağlamak ve üçüncüsü ise kimlik, kültür farklılıklarına karşı saygı duymak, duyarlı olmaktır (Erzurumlu, 2008, s.90). Çokkültürlülük bakanlığının birçok konuda örnek işlere imza attığı da açıkça görülmüştür. Örneğin normalde yasak olduğu halde dininin bir gereği olarak kama taşımak zorunda olduğu bilinen bir Sih müminine resmi görevi esnasında kama taşıma özgürlüğü; yine dini gereği başına sarık geçirmesi gereken bir Hintliye bu özgürlüğü tanımıştır. Yine başka bir örnekte, yerli bir grup, geleneklerinde yeri olduğu gerekçesiyle "balina avlama hakkı" talep etmiş ve normalde yasak olduğu halde kültürel farklılıklarına saygı çerçevesinde bu hakkı elde etmeyi başarmışlardır (URL-3). Yine bakanlık bir diğer politikasında, farklı etnik grupların çoğalmalarını ve fonksiyonlarının artmasını finanse ederek adetlerin devamını sağlamayı, göçmen ve yerli dillerinin korunmasını amaçlamıştır. Bu etno-kültürel vakıf ve dernekler devlet tarafından desteklenmekte ve her türlü yerel organizasyonlarının finansal desteği bakanlık tarafından karşılanmaktadır. Ayrıca "Miras Kültürler ve Diller Programı" çerçevesinde İngilizler ve Fransızlar dışındaki kültürlerin sanatsal üretimlerini yaymak, geliştirmek ve bu dilleri öğretmek için her türlü materyalin tedariği ve öğretmenlerin ücretleri bakanlık tarafından karşılanmaktadır (Erzurumlu, 2008, ss.65-66). Dolayısıyla tüm bu yapılan uygulamalar Kanada' nın çokkültürlülükte ne kadar ısrarcı ve başarılı bir tutum sergilediğini bizlere göstermektedir. Hayata geçirilen tüm bu pratikler ülkenin çokkültürlü bir toplum olduğunu tüm dünya ülkelerine göstermesi bakımından önem arz etmektedir. Kanada bu politikayla Mevlana' nın "ne olursan ol yine gel" sözünün adeta hayata geçirilmiş bir biçimini oluşturmuştur. Ülke hiçbir din, dil, ırk, kültür farkı gözetmeksizin herkese kapılarını sonuna kadar açmakta ve bu farklılıkların huzurlu bir şekilde bir arada yaşayabilmelerine imkan tanımaktadır. 
Kanada çoğulculuğunun en önemli göstergelerinden birisini ise dil çeşitliliği oluşturmaktadır. Örneğin 2011 yılı nüfus verilerine göre, nüfusun yüzde 57.8'i İngilizce, yüzde 21.7'si ise Fransızca konuşmaktadır. Bunların dışında Çince, İspanyolca, Arapça, İtalyanca, Urduca ve Almanca konuşulan diğer dillerdendir. Ayrıca birçok yerli dil de yaygın bir biçimde konuşulmaktadır (Dewing, 2009, s.2). Bu bağlamda bakıldığında Kanada'ya her yıl ortalama 70 bin mülteci ve göçmen gelmekte ve yine sadece Toronto' da 109 farklı kültüre ait dernek faaliyet göstermektedir. Ayrıca Toronto'da 100'den farklı dil konuşulmaktadır (Özensel, 2013a, s.10).

Çok başarılı bir göçmen politikası izleyen Kanada, göçmenlerin istihdamı ve kendi kedilerine yeterlilikleri konusunda da çalışmalar yapmaktadır. Bu bakımdan da Avrupa' dan keskin bir biçimde ayrılmaktadır. Örneğin 2004 yılının OECD verilerine göre yerli Kanada'llar (Kanada doğumlu olanlar) arasında işsizlik oranı yüzde 6.5 iken Kanada'ya dişarıdan göç edenler (Kanada dışında bir yerde doğanlar) arasında bu oran yüzde 7.8' dir. Avrupa ülkelerine bakıldığında ise aradaki bu farkın çok fazla açıldığı görülmektedir. Avusturya'da bu oran yüzde 4.3'e yüzde 11.2 düzeyindeyken, Hollanda'da yüzde 3.6'ya yüzde 10.3 seviyelerindedir. Bu veriden de anlaşılacağı gibi Avrupa ülkeleri göçmenlerin istihdamı konusunda faydalı politikalar üretememektedir (Banting, 2010, s.806).

Kanada çokkültürlülüğünün başarısına başka bir örnek olarak Bloemraad'ın Toronto ve Boston şehirlerindeki Vietnamlı göçmenlerin entegrasyonu üzerine yapmış olduğu çalışması gösterilebilir. Bloemraad yapmış olduğu çalışmasında bu farklı iki gruptaki göçmenlerin benzer eğitim, dil ve ekonomik seviyeleri olmasına karşın Toronto'ya yerleşenlerin politik anlamda daha etkili bir biçimde entegre olduklarını saptamıştır. Aynı şekilde Portekiz'den gelenlerde Boston'a göre Toronto'da daha iyi bir biçimde entegrasyon sağlamışlardır. Ayrıca Kanada'daki göçmenlerin eğitimleri üzerine düzenlenen OECD raporunda, okullardaki dilsel ve kültürel çeşitlilik üzerine üretilen politikaların başarılı sonuçlar verdiği gösterilmiştir (Kymlicka, 2012, ss.10-11).

Yukarıdaki iki örnek çalışma değerlendirildiğinde, Kanada' nın çokkültürlülük politikalarında daha işlevsel ve verimli çalışmalar yürüttüğü açıkça görülmektedir. Özellikle Batı ülkelerinin çokkültürlülük politikalarından tavizler vermesi ve Müslüman ülkelerden gelen göçmenlere karşı 
ayrımcı bir tutum sergilemesi de bu durumu destekler niteliktedir. Özellikle son dönemde Suriyeli göçmenler bağlamında yaşanan tartışmalar ve gelişmeler Avrupa'nın hem kendi içerisinde hem de dünya perspektifinde çokkültürlü bir birlikteliğe ve anlayışa sahip olup olmadığı yoğun bir biçimde tartışılmakta ve eleştirilmektedir.

Kanada' nın çok fazla göçmen alıyor olması kuşkusuz ki ülkede bir takım sorunlarında yaşanmasını da kaçınılmaz kılmıştır. Bu açıdan bakıldığında 1867 yılında Kanada devletinin kurulmasının akabinde çokkültürlülükten kaynaklanan ilk sorunlar yaşanmaya başlanmıştır. Manitoba'da Katolik Kilisesinin dinsel eğitim özgürlügünü kısıtlayan programa uymak istememesi ve hükümetin Katolik okullarına yardımı kesmesi sorunları büyütmüştür. Bunun sonucunda ise Macdonald Hükümeti iktidarını kaybetmiş ve yerine yeni bir hükümet kurulmuştur (Erzurumlu, 2008, s.59).

\section{Kanada Çokkültürlülüğün Kırılma Noktası: Quebec Sorunu}

Quebec eyaleti Kanada' nın en büyük eyaletlerinden birisi olup, 8 milyondan fazla kişinin yaşadığı bir bölge konumundadır. Bu eyaleti diğerlerinden farklı kılan önemli bir durum söz konusudur. Quebec, Kanada sınırı içerisinde Fransızcanın konuşulduğu tek yerleşim yeridir. Aynı zamanda da bu bölge Kanada hükümetine karşı direnmelerden ve görüşmelerden sonra taleplerinin yerine getirilmesi konusunda başarı sağlayabilmiş bir yerdir. Fransız kimliklerini korumaya yönelik verdikleri bu mücadele Quebec bölgesini çokkültürlülük uygulamaları ve politikaları ele alınırken göz ardı edilemeyecek bir konuma taşımıştır.

Kanada çokkültürlülüğü tartışmalarında Fransızların çoğunlukta yaşadığı Quebec bölgesinin bağımsızlık sorunu önemli bir yer tutmaktadır. Bu kapsamda 1980 ve 1995 yıllarında iki referandum yapılmış (Kalaycı, 2008, s.152), her iki referandumda da hayır oylarının çoğunlukta çıkması nedeniyle Quebec bağımsızlığını ilan edememiştir. Aslında Quebec meselesi daha eski bir tartışmaya dayanmaktadır. Fransızların yoğunlukta yaşadığı bu bölgenin 1759 yılında İngilizler tarafından işgal edilmesi bu bağımsızlık mücadelesinin başlangıcını oluşturmaktadır (Anık, 2012b, s.144). Diğer bir ifadeyle Kanada'nın 1971 yılında federal çokkültürlülük politikasını kabul etmesinde temel hedeflerinin arasında 1960'lı yıllarda 
yeniden patlak veren Quebec milliyetçiliği meselesinin olduğunu söylemek doğru olacaktır. Federal hükümet bu ayrılıkçı hareketi köreltmek için bir takım düzenlemelerin devreye sokulmasını sağlamıştır (Kymlicka, 2015, s.19).

Quebec'teki Fransızca konuşan topluluk kendi tarihine, diline, yasal sistemine, değerlerine, dünyadaki yerlerine ilişkin görüşlerine, farklı insanlar olduklarına dair toplu bir bilince sahip, ayrı bir kültürel topluluk olduklarını iddia etmektedirler. Onlara göre kendi yerel kimlikleri federal hükümetin ve Quebec'teki ekonomik ve dil yoğunluğu açısından baskın bir konumda olan İngilizlerin baskısı nedeniyle her geçen gün erimektedir. Dolayısıyla da onlara göre bu durumdan tek çıkış yolu ise Quebeclilere daha geniş politik özerklik tanınmasından geçmektedir (Parekh, 2002, ss.236-237). Bu açıdan bakıldığında ise verilen mücadelelerden sonra ilk olarak dil ile ilgili bazı yasaları parlamentodan geçirebilmeyi başarmışlardır. Örneğin çocuklarını İngilizce eğitim veren okullara kimlerin göndereceğini düzenleyen yasaya göre, Fransızca konuşanlar ya da diğer göçmenler bu okullara çocuklarını gönderemezler. Yine başka bir yasa, elliden fazla kişi çalıştıran şirketlerde kullanılacak dilin Fransızca olmasını zorunlu hale getirir. Üçüncü bir yasa ise ticari sözleşmelerin Fransızcadan başka her hangi bir dilde hazırlanmasını ve imzalanmasını yasaklanmaktadır (Taylor, 2000, s.63). Quebeclilerin bir başka temel talebi ise Quebec kimliğinin etnik bir unsur olmaktan ziyade ulusal bir kültür olarak tanınmasını içermektedir. Quebecliler Kanadalıların kendilerini ayrı bir toplum olarak tanıması isterken, kendilerini Kanada devletinin kurucu iki unsurundan birisi olarak da görmektedirler (Kalayc1, 2007, s.12).

Yaşanan tüm bu süreçten sonra ise Quebecliler Kanada hükümetinden istediklerinin çoğunu almayı başarmış gözükmektedir. Quebec' in elinde göç üzerinde büyük bir denetim hakkı, Fransız dilini geliştirmek için gerek duyulan güçlerin çoğu, kendi emeklilik planlarını yapabilme ve yurt dışında diplomatik temsil hakkı, federal hükümetten yıllık olarak ödediği vergilerden 3.1 milyon Kanada doları fazla ödenek almak ve geçilen 30 yıldan bu yana Kanada Başbakanlarının Quebec'li olması gibi birçok ayrıcalık ve özgürlük elde etmeyi başarmışlardır (Parekh, 2002, s.238).

Bu bağlamda Quebec modeli önümüzde önemli bir tarihsel süreç ve model olarak durmaktadır. Bu modelin iyi analiz edilip incelenmesi, çok- 
kültürlülük olgusunu daha uygulanabilir kılması açısından önem arz etmektedir. Yerel kültürlerinin baskın kültür tarafından ezilmesine izin vermeyen bu topluluk hem asimilasyon sürecinden kurtulmuş hem de belki tahmin bile edemeyecekleri haklara kavuşmuşlardır. Böyle bir örneğin Kanada çokkültürlü toplumu içerisinde ortaya çıkması ise ülkenin çokkültürlü politikalar üretmedeki başarısını kanıtlar bir niteliktedir.

\section{Sonuç}

İçerisinde yaşadığımız yüzyıl o kadar çok gelişmeyi ve ilerlemeyi içerisinde barındırmaktadır ki, bu süreçleri takip etmek zaman zaman imkânsızlaşmaktadır. Bu dönemde herkesin istediği her ne ise o şeye çok kolaylıkla ulaşabiliyor olması artık sınırların ve mesafelerin ortadan kalkmasını sağlamıştır. Bu durumun en belirgin örneği ise kültürlerin homojenleşmesi, iç içe girmesi ve birbirlerini etkilemesiyle sonuçlanmıştır. Çokkültürlülük de bu entegre olmanın bir adı olarak anılmaya başlanmıştır.

Dünyamızın hızla globalleşmesi nasıl ki bu yoldan geri dönüşün mümkün olmadığını bize gösteriyorsa, artık çokkültürlülükten, yani farklı kültürlerin bir arada yaşaması durumundan da geriye dönüş mümkün gözükmemektedir. Dolayısıyla artık salt çokkültürlülük meselesi üzerine tartışmak yerine farklı kültürlerin birbirleriyle uyumu nasıl sağlanabilir sorusu üzerine yoğunlaşmak, problemlerin çözümü adına daha akıllıca bir yaklaşım olarak görünmektedir. Bu durumun farkında olan ülkelerin başında da Kanada gelmektedir. Kanada çokkültürlülükten geriye dönüşün artık mümkün olmadığını kavramanın verdiği bilinçle, sınırları içerisinde yaşayan farklı etnik kültürlerin dertlerini, sorunlarını ve isteklerini dinleyip çözüm yolu sunmayı kendisine amaç edinmiş bir ülke konumunda olup dünyaya örnek bir çokkültürlü toplum modeli sunmayı başarmıştır. Çokkültürlülük tartışmalarında önemli bir nokta olarak görülen Quebec'in bağımsızlık meselesi halen tartışılıyor olsa da, Kanada hükümeti bu konunun üstesinden gelmiş gibi gözükmektedir. Quebec'lilerin taleplerini üretmiş olduğu politikalar neticesinde temel düzeyde yerine getiren Kanada hükümeti bu anlamda bir başarı göstermiştir.

Çokkültürlülük tartışmalarında kaçırılmaması gereken önemli bir nokta ise Batı ve Amerika merkezli çokkültürlülük politikalarıyla Kanada çokkültürlülük politikalarının birbirlerinden ayrılması gerektiğidir. Bu 
anlamda da Kanada çokkültürlülük modelinin bir üst model olduğunu söylemek hatalı olmayacaktır. Kuşkusuz ki böyle bir yargıda bulunulmasının bir takım gerekçeleri söz konusudur. Özellikle son dönemde yaşanan gerek Amerika'daki gerekse Avrupa'daki birçok olay Batı'nın çokkültürlülük politikalarından vazgeçtiğini ya da çokkültürlülük gibi bir konu da bile bazı dinsel, ırksal vb. nedenlerle insanların ayrımcılığa tabi tutuldukları görülmektedir. Örneğin Amerika' daki siyahilere yönelik ırkçı uygulamalara gidilmesi, yine dünya gündemini sıkça meşgul eden Suriyeli mültecilerin durumu konusunda Batı'nın çelişkili ve ayrımcı politikaları ve buna benzer birçok olayın yaşanması insanların çokkültürlülük kavramını sorgulamasına neden olmaktadır.

Son söz olarak, çokkültürlü bir toplum olabilmenin temel şartının birbirini anlamaya çalışmaktan geçtiğini söyleyebiliriz. Üst kimlik olarak insanın belirlenmesi, insana insan olduğu için değer verilmesi ve birey olarak herkesin biricik olduğunun farkında olunması, alt kültürü (din,dil,ırk,...) oluşturan öğelerin mutlu ve huzurlu yaşama konusunda çok da önem arz etmediği bizlere gösterecektir. Farklılıkların zenginlik olarak görülmesi, hoşgörünün ön plana çıkarılması ve bu çerçevede bir hukuk sisteminin oluşturulması kusursuz olmasa da en azından en az kusurlu ve uygulanabilir bir çokkültürlülük anlayışının oluşmasında etkili olabilecektir.

\section{Kaynakça}

Anık, M. (2012a). Çokkültürcülük ve osmanlı devleti, Selçuk Üniversitesi Edebiyat Fakültesi Dergisi, Sayı: 27, 117-130.

Anık, M. (2012b). Kimlik ve çokkültürcülük sosyolojisi. İstanbul: Açılım Kitap.

Bağlı, M. ve Özensel, E. (2005). Çokkültürlü vatandaşlık. Konya: Çizgi Yayinları.

Banting, G. (2010). Is there a progressive's dilemma in canada? Immigration, multiculturalism and the welfare state, Canadian Journal of Political Science.

Dewing, M. (2009). Canadian multiculturalism, Library of Parliament. 
Erzurumlu, S. (2008). Çokkültürcülük politikası ve Kanada' da çokkültürcülük. Isparta: S.D.Ü Yüksek Lisans Tezi.

Forbes, D. H. (2007). Multiculturalism and the canadian constitution, Edited by Stephen Tierney, Trudeau As the First Theorist of Canadian Multiculturalism, UBC Press.

Kalaycı, H. (2007). Kanada quebec sorunu, çokkültürcülük, kendi kaderini tayin, milliyetçilik ve federalism. Ankara: Ankara Üniversitesi, S.B.E, Doktora Tezi.

Kalaycı, H. (2008). Referandumla ayrılma konusunda yüksek mahkemenin tutumu: kanada-quebec örneği, Ankara Üniversitesi SBF Dergisi, 63(1), 151-174.

Kymlicka, W. (2012). Multiculturalism: success, failure and the future, Migration Policy Institute.

Kymlicka, W. (2015). The three lives of multiculturalism, Revisiting Multiculturalism in Canada Theories, Policies and Debates, (Eds: Shibao Guo and Lloyd Wong), Sense Publishers.

Özensel, E. (2012). Çokkültürlülük uygulaması olarak Kanada çokkültürlülüğ̈̈, Akademik İncelemeler Dergisi, 1(7), 55-70

Özensel, E. (2013a). Doğu toplumlarında ve Türkiye'de birlikte yaşama arayışı: çokkültürlülük mü? yoksa yeni bir model mi?, Akademik Incelemeler Dergisi, 8(3), 1-17.

Özensel, E. (2013b). In search of coexistence in eastern societies: multiculturalism or a new model? International Journal of Sustainable Human Development, 1(2), 19-26.

Parekh, B. (2002). Çokkültürlülüğü yeniden düşünmek, (Çev: Bilge Tanrıseven). İstanbul: Phoenix Yayınları.

Sengstock, C. M. (2009). Voices of diversity multi-culturalism in America, Springer Media.

Strauss, L. C. (1995). Irk, tarih ve kültür, (Çev: Haldun Bayrı v.d.). İstanbul: Metis Yayınları.

Şan, M. K. ve Öğür, B. (2016). Çokkültürlülük söylemleri ve milliyetçiliğin dönüşümü, Bilgi Ekonomisi ve Yönetimi Dergisi, 11(1), 131-142.

Taylor, C. (1995). Modernliğin sıkıntıları, (Çev: Uğur Canbilen), İstanbul: Ayrıntı Yayınları.

Taylor, C. (2000). Çokkültürcülük (tanınma politikası), (Haz: Amy Gutmann), İstanbul: Yapı Kredi Yayınları. 
Vatandaş, C. (2001). Çokkültürlü yapıda ulusal/etnik kimlikler(Kanada örneği), A.K.Ü. Sosyal Bilimler Dergisi, 3(2), 101-117.

\section{Internet Kaynakları}

http://www.canadainternational.gc.ca, 15.05.2012. (URL-1)

http://tr.wikipedia.org/wiki/Kanada, 18.05.2012. (URL-2)

http://yenisafak.com.tr/Yazarlar/?i=7045\&y=YasinAktay, 14.05.2012.

(URL-3)

\section{Kaynakça Bilgisi / Citation Information}

Başaran, E. (2017). Çokkültürlülük Olgusunun Kanada Örneği Ekseninde İncelenmesi, OPUS - Uluslararası Toplum Araştırmaları Dergisi, 7(12), 237-253. 